\title{
THE RISK ASSESSMENT MODEL WHEN SELECTING A FOREIGN SUPPLIER UNDER AN INTERNATIONAL TRADE CONTRACT
}

\author{
O. Martyanova ${ }^{1}$ \\ DOI: http://doi.org/10.15350/L_2/2/5
}

Abstract

The paper presents the methodical toolware of risk assessment when selecting a foreign supplier that is the mandatory component of the internal control system, which should ensure effective international trade activities including risk management through a sequence of analytical procedures, prevent or minimize possible losses by influencing the factors initiating occurrence of risks in performance of an international trade contract.

Keywords: international trade contract, internal control, foreign supplier, model of risk assessment, multi-criteria analysis, uncertainty factors, efficiency of international trade

Relevancy of selecting a foreign supplier within performance of an international trade contract is conditioned by an increase in the international trade which largely depends on the role of leading companies in the world market, the corporate structure of the international trade, organizational and legal forms of foreign companies.

A supplier can be chosen in several ways. The first one is the selection of a counterparty on the basis of the received proposals analysis according to the criteria developed by a company. In this case, the company itself determines the supplier selection criteria, for example, a contract price level. The second method of choosing a supplier is based on the principle of collective discussion of foreign counterparty possibilities to meet a company's requirements. In any case, in order an evaluation model selected by a company ensures the expected effect, it should reflect significant international trade relations and include their actual forms.

Figure 1 shows the relationships in the model of the international trade contract performance analysis taking into account the interaction of both external and internal process participants as well as respective databases. The model is based on the collection, processing and presentation of data that after undergoing the economic analysis allow for risk estimation for selecting a particular foreign supplier.

A company should make an analysis of a potential supplier taking into account the laws regulating transport, financial, legal aspects of the international trade, that will ensure an adequate decision on the feasibility of a contract. In any

\footnotetext{
10lga Martyanova, Candidate of Economic Sciences, doctoral candidate The Orel State University of Economics and Trade, Russia.
} 
case, new contracts with foreign contractors require due diligence from a company as it is emphasized by the Plenary Assembly of Supreme Arbitration Court of the Russian Federation in its Decision No.53 of October 12, 2006 [1].

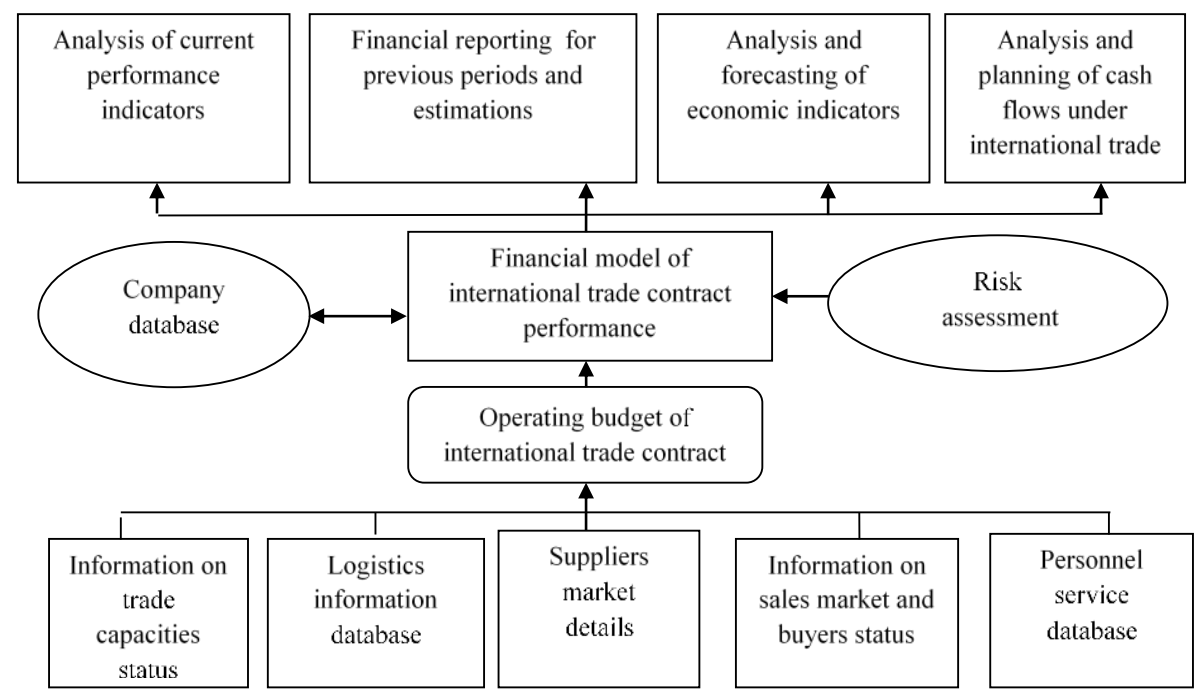

The source: prepared by the author

Figure 1. The diagram of relations in the model of the international trade contract performance analysis

However, it is very difficult to identify an unfair supplier as it is located outside the country and the list of actions that a company needs to perform to confirm due diligence is not legally established. As at the present stage Russia is only shaping the system of providing international trade participants with such proper information, it makes sense for a company to form its own database for the analyses applied in its international trade activity. The range of such data sources is wide. So, accounting information can be obtained from accounting (financial) statements of the company; planning information is included into the business plan, production programs, operational tasks, flow process charts. Marketing data is provided by the Chamber of Commerce and Industry, the All-Russian Market Research Institute; published in reviews by international information and consulting agencies, in economic journals, internet; contained in materials of international exhibitions and fairs. The analysis of a brand structure of the market to which a business entity is planning to enter, identification of companies having a competitive advantage in the market in offering a particular product, study of relations between potential partners, evaluation of their production capacity and commodity prices will enable a company to obtain information necessary for selection of a foreign supplier. So, a company can obtain information about foreign contractors from different sources based on requirements to analysis results. 
Regardless of the specifics of the international trade, a company size, characteristics of goods life cycle, the most important indicators in the evaluation and selection process are the following: reliability of a commodity contract (observance of established volumes and terms of delivery); quality of goods (delivery of goods in accordance with its specification); price acceptability (considering all costs for purchase of a particular product, i. e. transportation, insurance, administrative expenses, risks of foreign exchange rate changes, customs charges and duties); remoteness of a supplier's production from the logistics infrastructure; the order follow-up term; a possibility to deliver a test batch of goods at the initial stage of an international trade contract; terms of delivery; a settlement procedure; image; packing; goods labelling; reserve capacities of a supplier.

It should be noted that western companies use the indicator scale proposed by Michael R. Linders and Harold E. Firon for selecting a counterparty, including quality of goods; timeliness of delivery; price of goods; service; offers to reduce a price for repeated delivery of goods; commercial and production capacities of a supplier; assessment of a supplier's finances [10, p. 92]. This fact makes it possible to state that the indicators used for selection of a foreign supplier are very diverse.

As for the system of indicators for choosing a foreign supplier, the company needs to form such a system prior the study process; upon the results of this process, based on a relevant amount of information and using selected methods a management decision should be made. At the same time, there may be the situations when a number of companies meet the system of indicators chosen by a business entity. In this case, in our opinion, the ranking analysis can help establish preference of any company as such analysis determines perspectives of the study, its stages and adequate evaluation criteria. However, since this process is not formalized, a final decision on the selection of a supplier should be made by the international trade participant.

Nevertheless, the results of assessment of competing companies' opportunities to perform an international trade contract within a specified term and at a required quality level are subject to influence by various types of uncertainties. Not taking such uncertainties into account may result in deviations of a future result from the expected one, which, in its turn, can lead to significant economic losses associated with unjustified financial costs of additional works and reduction of accuracy of planning activities of a business entity for a long-term period. All the above mentioned suggests the approach to study of uncertainties in the selection of a foreign supplier under inaccuracy of the initial data that is based on the analysis of possible values of a number of indicators using probabilistic models. It will give an opportunity to effectively attain the objectives of such study.

In our opinion, the analysis of the uncertainties influence on selecting a foreign supplier for performance of an international trade contract requires assessment of risks associated with selecting a counterparty from many available alternatives. This procedure should be simple, rational and guarantee quantitative risk assessments, which have two features: multicriteriality (risks may be 
presented as hierarchies with different levels of nesting); and the collective nature of the decision-making on a probability of adverse events and the size of losses associated with these events. The procedure of collective decision-making on the risk value by estimating losses and a probability of adverse events can be considered as application of the expert evaluation method [8, p. 212] which determines objective criteria of expert evaluations and conclusion reliability.

The decision-making process of selecting a foreign supplier can be presented by three task classes: the choice of the best alternative; classification of alternatives; ranking of alternatives; as decision-making in the international trade is the activity aimed at finding a better alternative in accordance with preferences of a business entity under uncertainty when assessment of alternatives is made according to many criteria. To substantiate this statement let us select a foreign supplier taking into account the conditions of the trade contract proposed by this supplier and apply the developed approach to selection of a counterparty in the following situations: (i) by the time a decision is taken many alternatives have been defined; (ii) by the time a decision is taken many alternatives have been unknown. As an information base for calculations we use the data disclosed by a manufacturer in its management reporting.

In this connection, we consider it necessary to form a hierarchy of criteria as an analysis of hierarchies is based on the system approach which forms a holistic pattern of an object and reveals the interaction of strategic factors with external environment due to external links and relations between elements of the structure, highlighting significant ones. It is confirmed by our studies, the results of which are presented in the papers $[2,3,4,5,6,7]$.

In this case, the problem of choosing is structured as a hierarchy, the top of which is the goal, intermediate levels are criteria, and the lower level is a set of alternatives. The analysis of this hierarchy due to relationships of each level gives an opportunity to evaluate the top level crowning the structure; and pairwise comparison of hierarchy elements defines a degree of their impact on a final parameter. In this context, the elements should be compared in pairs to define their impact on their common characteristics. The consequence of pairwise comparison of hierarchy elements is an antisymmetrical matrix; and an expert's judgment concerning the significance of criteria for evaluation is reflected in the pairwise comparison matrix. It should be noted that the method of the hierarchy analysis includes synthesis of many opinions on the importance of criteria and finding alternative solutions $[9, \mathrm{p} .83]$.

The rationale for the system approach to the problem of selecting a foreign supplier under economic uncertainty makes it possible to offer a hierarchical model of selecting a foreign counterparty for performance of an international trade contract. This model is presented as a diagram in Figure 2. 


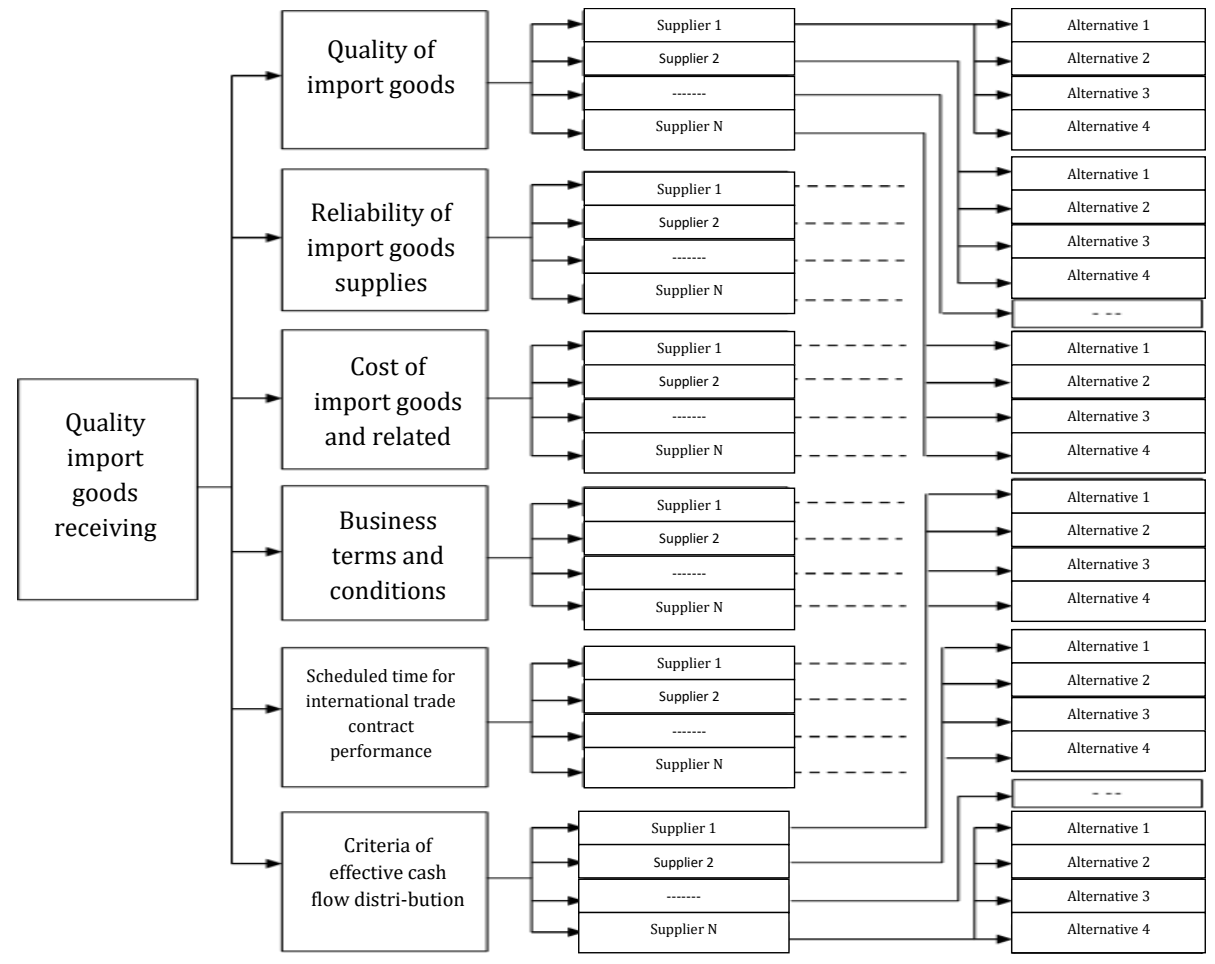

The source: prepared by the author

Figure 2. The hierarchical model of selecting a foreign supplier

At the first level of the model there are the main factors influencing the choice of foreign companies supplying imported goods; at the second level there are suppliers of imported goods (their number may vary); the third level is a set of alternatives which are the basis for the choice: A1 is a tight schedule to perform a contract and low quality of goods as the subject of an international trade contract; A2 is greater terms to perform and low quality of goods as the subject of an international trade contract; $\mathrm{A} 3$ is greater terms to perform and high quality of goods as the subject of an international trade contract; A4 is a tight schedule to perform a contract and high quality of the subject of an international trade contract. Upon compiling the hierarchy a lot of pairwise comparison matrices are constructed.

The element comparison is made under the preference principle that helps form local priorities using a set of pairwise comparison matrices reflecting the degree of influence of the same level hierarchy elements on many elements included into the next higher level of the hierarchy. After this procedure the set of vectors is calculated for each pairwise comparison matrix, and then the priority vector is formed [9, p. 70].

The choice of a foreign supplier depends on the criteria established by a company; the essence of these criteria reveals the specifics of risks associated with selecting a foreign counterparty. In this regard, for the adequate solution of the 
task the hierarchy of criteria was formed; its first level consists of customer feedback (KO1), financial characteristics of a potential supplier activity (FS1) and availability of goods (TN1) (Figure 3).

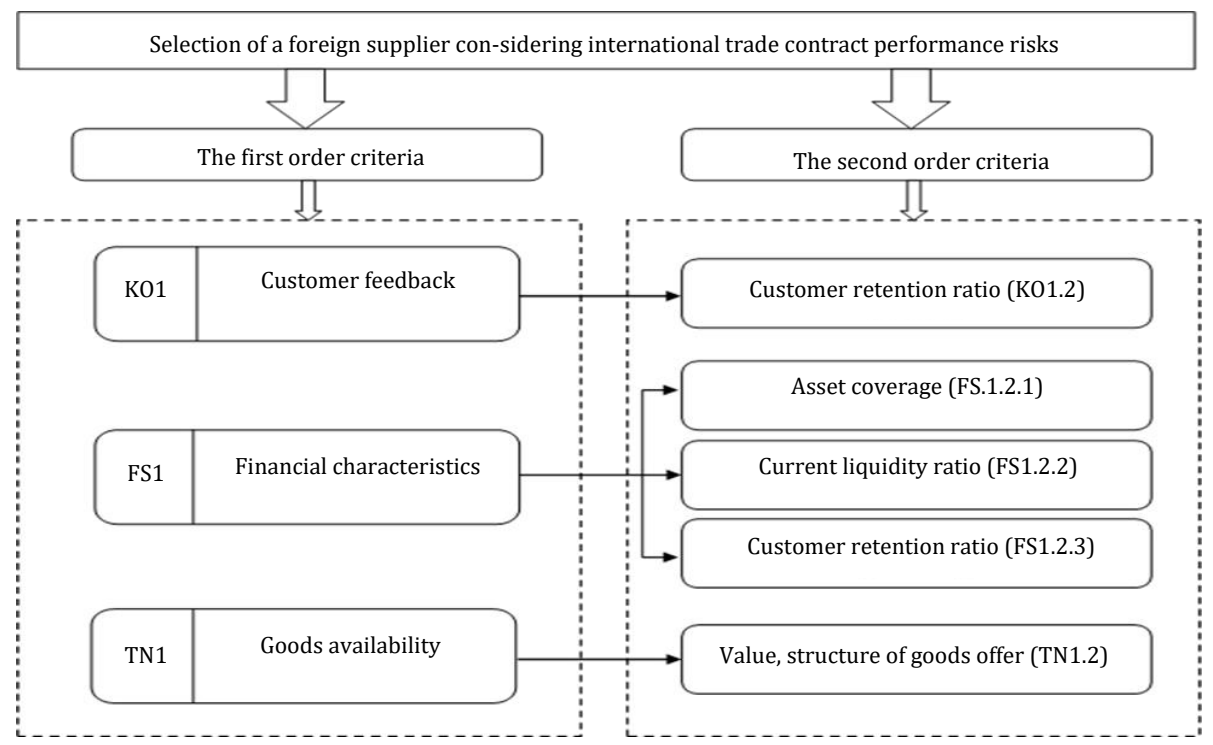

The source: prepared by the author

Figure 3. The criteria for evaluation of a foreign supplier taking into account risks of international trade contract performance

This choice of criteria is based on the fact that customer feedback is one of the means to adequately evaluate not only a product of a supplier, but also its activities in the market, financial characteristics provide an opportunity to assess a financial status of a potential contractor by formal indicators, and availability of goods expresses the factor of time when a contract will be performed.

The second order criteria include such a parameter as the customer retention ratio (K01.2) which is easy to understand, to calculate, helps identify a target segment, generates feedback being of practical interest for a company, facilitates quick decision-making providing a business entity acting in the field of the international trade with competitive advantages. The financial characteristics include such indicators as asset coverage (FS.1.2.1) characterizing the assets formed from a company's own capital; the current liquidity ratio (FS1.2.2) as it gives an overall estimation of current asset liquidity; receivable turnover (FS.1.2.3) as turnover acceleration not only maintains a high level of solvency, but also increases the international trade scope. The volume and structure of a goods offer (TN1.2) expresses competitiveness of a foreign supplier.

For pairwise comparison of the selected criteria and alternatives the Saati ratio scale (Table 1) [9, p. 53] supplemented and improved by A. A. Perminov was used; it helps estimate preference of a criterion located in a line of the pairwise comparison matrix in relation to a criterion in its column [8, p. 217]. 
The scale of criteria and alternatives preference assessment

\begin{tabular}{|c|c|c|}
\hline $\begin{array}{l}\text { Degree of } \\
\text { preference }\end{array}$ & Value & Description \\
\hline 1 & Equal importance & Two alternatives are equally important \\
\hline 2 & Low degree of superiority & Intermediate value \\
\hline 3 & $\begin{array}{l}\text { Moderate degree of superior- } \\
\text { ity }\end{array}$ & $\begin{array}{l}\text { One alternative is slightly preferable to an- } \\
\text { other }\end{array}$ \\
\hline 4 & Above average superiority & Intermediate value \\
\hline 5 & Moderately strong superiority & $\begin{array}{l}\text { One alternative is apparently preferable to } \\
\text { another }\end{array}$ \\
\hline 6 & Significant superiority & Intermediate value \\
\hline 7 & Very significant superiority & $\begin{array}{l}\text { Alternative domination is confirmed by prac- } \\
\text { tice }\end{array}$ \\
\hline 8 & Unchallenged superiority & Intermediate value \\
\hline 9 & Absolute superiority & $\begin{array}{l}\text { One alternative is indisputably preferable to } \\
\text { another }\end{array}$ \\
\hline
\end{tabular}

This approach to selecting a foreign supplier makes it possible to present the results of pairwise comparison of the first level criteria preference in the form of Table 2 containing the values of the maximum eigenvalue of the matrix $\left(n_{\max }\right)$, the stochastic consistency index $(R I)$ and the consistency index $(C R)$ defined by the following ratio [9, p. 23]:

$$
C R=\frac{C I}{R I}
$$

where $C I=\frac{n_{\max }-n}{n-1}$ is the matrix consistency index;

$R I=\frac{1.98(n-2)}{n}$ is the stochastic consistency index of the matrix.

Table 2

The matrix of pairwise comparisons of the first order criteria

\begin{tabular}{|c|c|c|c|c|c|c|c|c|}
\hline The criterion & K01 & FS.1 & TN1 & $n_{\max }$ & $C I$ & $R I$ & $C R$ & $\begin{array}{c}\text { Global } \\
\text { priority }\end{array}$ \\
\hline K01 & 1 & 3 & 8 & & & & & 0.669 \\
\hline FS.1 & $1 / 3$ & 1 & 4 & 3.028 & 0.014 & 0.660 & 0.021 & 0.257 \\
\hline TN1 & $1 / 8$ & $1 / 4$ & 1 & & & & & 0.074 \\
\hline
\end{tabular}

The analysis of global priorities, the values of which are presented in Table 2, shows high importance of customer feedback, experience of work over financial characteristics; available supplier's goods has the last position.

The priorities of the alternatives associated to the Financial Characteristics criterion are defined on the basis of systematization of the study results that gave the matrix of their pairwise comparisons (Table 3).

Table 3

The matrix of pairwise comparisons of the second order alternatives of the Financial Characteristics criterion

\begin{tabular}{|c|c|c|c|c|c|c|c|c|}
\hline $\begin{array}{c}\text { The cri- } \\
\text { terion }\end{array}$ & FS.1.2.1 & FS.1.2.2 & FS.1.2.3 & $n_{\max }$ & $C I$ & $R I$ & $C R$ & $\begin{array}{c}\text { Global } \\
\text { priority }\end{array}$ \\
\hline FS.1.2.1 & 1 & 7 & 1 & & & & & 0.451 \\
\hline FS.1.2.2 & $1 / 7$ & 1 & $1 / 9$ & 3.009 & 0.005 & 0.660 & 0.007 & 0.059 \\
\hline FS.1.2.3 & 1 & 9 & 1 & & & & & 0.490 \\
\hline
\end{tabular}


Evaluation of the Table 3 data shows that coverage of equity capital has the very significant priority over probability of bankruptcy and is almost equal to the possibility of working without prepayment. The second line of the matrix indicates that significance of the bankruptcy probability is drastically low than the possibility of working without prepayment. In our opinion, such results can be explained by the fact that performance of an international trade contract for purchase of goods under prepayment involves extraction of funds or other liquid assets out of turnover and there is "tying" of an importer's capital for the period until receiving goods. But a foreign supplier is restricted in the commodity credit arrangements with Russian importers by the low level of their payment discipline because in this case it will be at risk of avoidance of a buyer from payment for goods delivered.

Within the study each criterion was involved into pairwise comparison of alternatives in terms of their compliance with this criterion. Systematization of analysis results in the context of each supplier help summarize the received materials and present them in the form of Table 4.

Table 4

The matrix of pairwise comparisons of alternatives in relation to the criteria

\begin{tabular}{|c|c|c|c|c|c|c|c|c|c|}
\hline Criterion & $\begin{array}{l}\text { Alter- } \\
\text { native }\end{array}$ & I & II & III & $n_{\max }$ & $C I$ & $R I$ & $C R$ & $\begin{array}{l}\text { Global pri- } \\
\text { ority }\end{array}$ \\
\hline \multirow{3}{*}{$\begin{array}{l}\text { Customer feed- } \\
\text { back }\end{array}$} & I & 1 & 1 & $1 / 4$ & \multirow{3}{*}{3.069} & \multirow{3}{*}{0.035} & \multirow{3}{*}{0.660} & \multirow{3}{*}{0.053} & 0.187 \\
\hline & II & 1 & 1 & $1 / 2$ & & & & & 0.234 \\
\hline & III & 4 & 2 & 1 & & & & & 0.579 \\
\hline \multirow{3}{*}{$\begin{array}{c}\text { Coverage } \\
\text { of equity } \\
\text { capital }\end{array}$} & I & 1 & 1 & $1 / 3$ & \multirow{3}{*}{3.022} & \multirow{3}{*}{0.011} & \multirow{3}{*}{0.660} & \multirow{3}{*}{0.017} & 0.211 \\
\hline & II & 1 & 1 & $1 / 2$ & & & & & 0.241 \\
\hline & III & 3 & 2 & 1 & & & & & 0.548 \\
\hline \multirow{3}{*}{$\begin{array}{c}\text { Probability } \\
\text { of bankruptcy } \\
\text { of the supplier }\end{array}$} & I & 1 & 1 & $1 / 2$ & \multirow{3}{*}{3.026} & \multirow{3}{*}{0.013} & \multirow{3}{*}{0.660} & \multirow{3}{*}{0.019} & 0.269 \\
\hline & II & 1 & 1 & $1 / 6$ & & & & & 0.118 \\
\hline & III & 2 & 6 & 1 & & & & & 0.613 \\
\hline \multirow{3}{*}{$\begin{array}{c}\text { No } \\
\text { prepayment }\end{array}$} & I & 1 & 2 & $1 / 2$ & \multirow{3}{*}{3.011} & \multirow{3}{*}{0.006} & \multirow{3}{*}{0.660} & \multirow{3}{*}{0.008} & 0.297 \\
\hline & II & $1 / 2$ & 1 & $1 / 3$ & & & & & 0.164 \\
\hline & III & 2 & 3 & 1 & & & & & 0.539 \\
\hline \multirow{3}{*}{$\begin{array}{l}\text { Availability } \\
\text { of goods }\end{array}$} & I & 1 & 2 & $1 / 7$ & \multirow{3}{*}{3.042} & \multirow{3}{*}{0.021} & \multirow{3}{*}{0.660} & \multirow{3}{*}{0.032} & 0.137 \\
\hline & II & $1 / 2$ & 8 & $1 / 8$ & & & & & 0.083 \\
\hline & III & 7 & 8 & 1 & & & & & 0.780 \\
\hline
\end{tabular}

Evaluating the compliance of each foreign supplier with five criteria we can note the following: in terms of positive feedback from other buyers Supplier III is the leader, Supplier I and Supplier II are equally attractive, but Supplier III has superiority above average in comparison with Supplier I and mild superiority over Supplier II.

In terms of coverage of equity capital Supplier I slightly falls short of the rest, and Supplier III is slightly superior to Supplier II leading in this criterion. The probability of bankruptcy is the worst for Supplier II, and the leader is Supplier III. In regard to the possibility of working without prepayment Supplier III is the leader as well as in terms of the Goods Availability criterion. 
A management decision on the selection of a foreign supplier can be made on the basis of comparative assessment of economic activities of potential counterparties. It required the compilation of Table 5. The analysis of the data shown in Table 5 enables us to recognize Supplier III as the best one.

Table 5

The results of comparative assessment of suppliers' economic activity

\begin{tabular}{|c|c|c|c|c|c|c|}
\hline \multirow{2}{*}{$\begin{array}{c}\text { Criterion } \\
\text { Alterna- } \\
\text { tive }\end{array}$} & K01 & FS.1.2.1 & FS.1.2.2 & FS.1.2.3 & TN1 & \multirow{2}{*}{$\begin{array}{l}\text { Global priority } \\
\text { of alternative }\end{array}$} \\
\hline & 0.669 & 0.451 & 0.059 & 0.490 & 0.074 & \\
\hline $\mathrm{I}$ & 0.187 & 0.211 & 0.269 & 0.297 & 0.137 & 0.391 \\
\hline II & 0.234 & 0.241 & 0.118 & 0.164 & 0.083 & 0.359 \\
\hline III & 0.579 & 0.548 & 0.613 & 0.539 & 0.780 & 0.993 \\
\hline
\end{tabular}

Choosing a foreign supplier, in our opinion, should involve the minimal risk as the risk is characterized by possible unforeseen losses affecting efficiency of the international trade of a company. Therefore, the next stage of the study is the choice of a supplier. This stage ensures performance of an international trade contract with the minimal risk. For evaluation of this risk two hierarchies were formed: probabilities of (i) an adverse event (Figure 4) and (ii) losses (Figure 5) as the risk value is the product of an adverse event probability $(P)$ and the amount of losses $(\eta)$ associated with this event [8, p. 212]:

$$
r=P \times \eta .
$$

Our studies of international trade contract performance by foreign counterparties have revealed the following adverse factors:

-failure to fulfil obligations under a contract by a foreign supplier (OP.1) that may be caused by partial fulfilment of obligations, which leads to outward investment unprofitability (OP.1.2.1) or refusal of a supplier to fulfil the terms of a contract resulting in the increase of cancelled contracts cost (OP.1.2.2);

-breach of goods delivery time schedule (SP.1);

-the change in goods value under an import contract (ST.1) that may be caused by changes of the market price of goods resulting in exceeding the budget approved for performance of a contract (ST.1.2.1) and penalties payable to a supplier (ST.1.2.2).

The adverse events may result in losses in supplies caused by non-compliance with goods volumes and delivery terms (PM1) characterized by the inventory turnover rate (PM1.2.1) and the turnover rate of payables (PM1.2.2), financial losses (penalties (PF.1.2.1) and additional costs (PF.1.2.2)), loss of competitiveness of a company (PI1) determined by a market share (PI1.2.1) and a share of profit in the total volume of import (PI1.2.2) as well as staff turnover, who refuse to assume the risks associated with performance of international trade contracts (PS.1.2). 


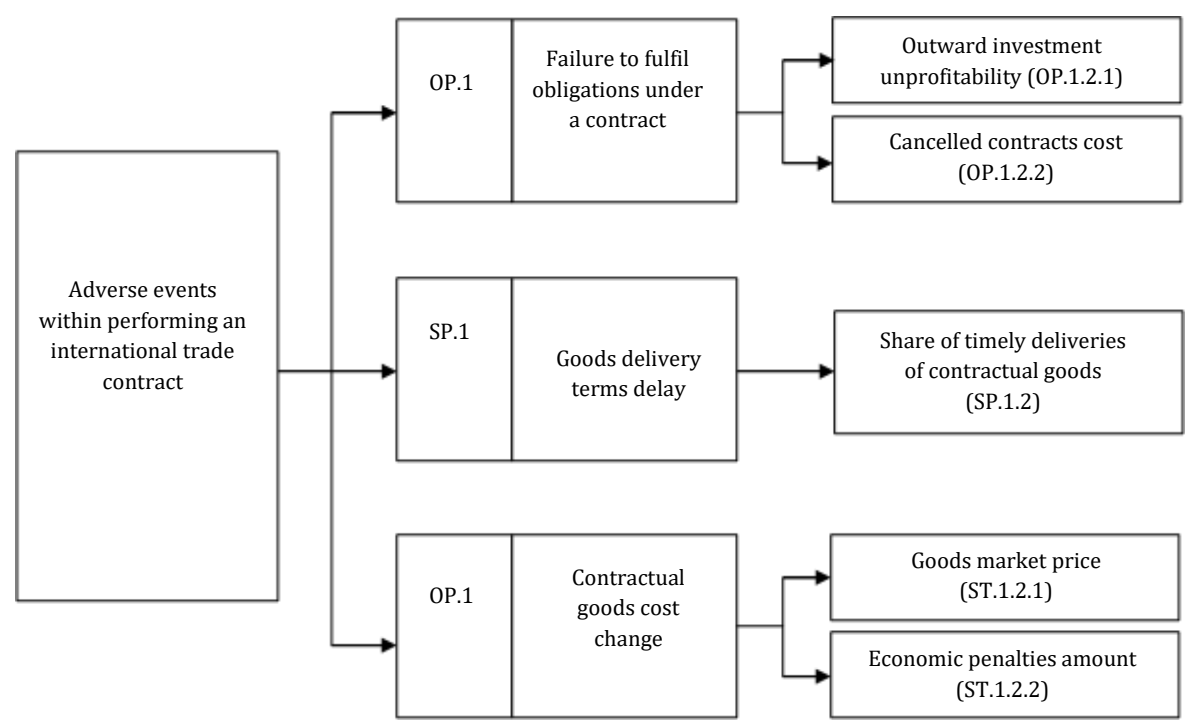

The source: prepared by the author

Figure 4 . The criteria for assessing the adverse event probability

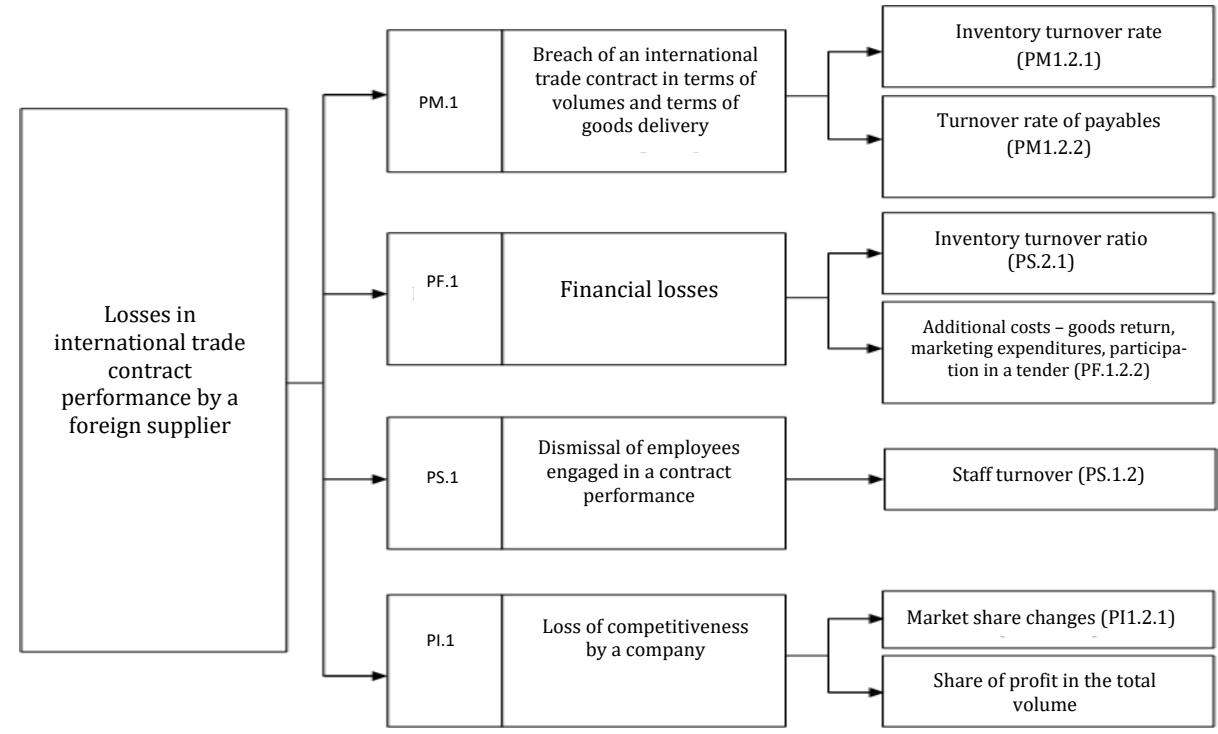

The source: prepared by the author

Figure 5. The criteria for estimating losses in international trade contract performance by a foreign supplier 
The mentioned criteria may be detailed further, but in general they present the main risks of performance an international trade contract by a foreign supplier, which are associated with terms, volumes, quality and cost of goods.

The criteria priorities indirectly characterizing significance of various problems related to performance of an international trade contract are defined in this study on the basis of the assessment of the adverse event probability in performance of that contract by a foreign supplier by calculating the maximum eigenvalue of the matrix $\left(n_{\max }\right)$, the consistency index $(C R)$, the stochastic consistency index $(R I)$, that permits to present the results of the calculations in Table 6 .

Table 6

The matrix of pairwise comparisons of the first order criteria

\begin{tabular}{|c|c|c|c|c|c|c|c|c|}
\hline Criterion & OP.1 & SP.1 & ST.1 & $n_{\max }$ & $C I$ & $R I$ & $C R$ & $\begin{array}{c}\text { Global } \\
\text { priority }\end{array}$ \\
\hline OP.1 & 1 & $1 / 4$ & $1 / 4$ & & & & & 0.110 \\
\hline SP.1 & 4 & 1 & 2 & 3.069 & 0.034 & 0.660 & 0.052 & 0.544 \\
\hline ST.1 & 4 & $1 / 2$ & 1 & & & & & 0.346 \\
\hline
\end{tabular}

The pairwise comparisons of the criteria based on the Table 6 data gave a possibility to establish that the failure to comply with delivery terms is most likely to be related to logistical issues. However, the probability of problems associated with a contract cost may be assessed as average, and the failure to meet contractual obligations is characterized by a minimal probability as shown in Tables 7 and 8, which present evaluations of the alternatives of the criteria selected by a company.

Table 7

The matrix of pairwise comparisons of the second order alternatives of the criterion "Failure to fulfil obligations under a contract"

\begin{tabular}{|c|c|c|c|c|c|c|}
\hline Criterion & OP.1.2.1 & OP.1.2.1 & $n_{\max }$ & $C I$ & $R I$ & Global priority \\
\hline OP.1.2.1 & 1 & 3 & & & & 0.750 \\
\hline OP.1.2.1 & $1 / 3$ & 1 & 2.000 & 0.000 & 0.000 & 0.250 \\
\hline
\end{tabular}

Table 8

Evaluation of the second order alternatives of the criterion "Import contract cost" on the basis of the pairwise comparison matrix

\begin{tabular}{|c|c|c|c|c|c|c|}
\hline Criterion & ST.1.2.1 & ST.1.2.2 & $n_{\max }$ & $C I$ & $R I$ & Global priority \\
\hline ST.1.2.1 & 1 & 2 & & & & 0.667 \\
\hline ST.1.2.2 & $1 / 2$ & 1 & 2.000 & 0.000 & 0.000 & 0.333 \\
\hline
\end{tabular}

Evaluation of the results of the pairwise comparison of the alternatives for each of the five criteria for assessing the probability of adverse events performed in the study shows that all the suppliers are equal in terms of the probability of incomplete fulfilment of obligations. However, the analysis of the Supplier II information suggests that it is prone to refuse to fulfil the obligations of complex contracts. 
The results of the pairwise comparison of the alternatives for each of the five criteria for assessing the probability of adverse events are presented in Table 9. It shows that in terms of the probability of incomplete fulfilment of obligations all suppliers are equal.

However, the analysis of the Supplier II information suggests that it is prone to refuse to fulfil the obligations of complex contracts.

Table 9

The analysis of the alternatives based on the criteria for assessing the probability of adverse events in performance of a contract

\begin{tabular}{|c|c|c|c|c|c|c|c|c|c|}
\hline Criterion & $\begin{array}{c}\text { Alterna- } \\
\text { tive }\end{array}$ & I & II & III & $n_{\max }$ & $C I$ & $R I$ & $C R$ & \begin{tabular}{|c} 
Global prior- \\
ity
\end{tabular} \\
\hline Partial & I & 1 & 1 & 1 & \multirow{3}{*}{3.000} & \multirow{3}{*}{0.000} & \multirow{3}{*}{0.660} & \multirow{3}{*}{0.000} & 0.333 \\
\hline performance & II & 1 & 1 & 1 & & & & & 0.333 \\
\hline of obligations & III & 1 & 1 & 1 & & & & & 0.333 \\
\hline \multirow{3}{*}{$\begin{array}{l}\text { Refusal of a supplier } \\
\text { from performing } \\
\text { of contract terms }\end{array}$} & I & 1 & $1 / 9$ & $1 / 2$ & & & & & 0.077 \\
\hline & II & 9 & 1 & 7 & 3.042 & 0.021 & 0.660 & 0.032 & 0.790 \\
\hline & III & 2 & $1 / 7$ & 1 & & & & & 0.133 \\
\hline \multirow{3}{*}{$\begin{array}{c}\text { Breach of an interna- } \\
\text { tional } \\
\text { trade contract in terms } \\
\text { of volumes and terms of } \\
\text { goods delivery }\end{array}$} & I & 1 & 4 & 3 & \multirow{3}{*}{3.013} & \multirow{3}{*}{0.006} & \multirow{3}{*}{0.660} & \multirow{3}{*}{0.010} & 0.633 \\
\hline & II & $1 / 4$ & 1 & 1 & & & & & 0.175 \\
\hline & III & $1 / 3$ & 1 & 1 & & & & & 0.192 \\
\hline \multirow{3}{*}{$\begin{array}{c}\text { Exceeding the } \\
\text { budget of performance } \\
\text { of a contract }\end{array}$} & I & 1 & 2 & 1 & \multirow{3}{*}{3.056} & \multirow{3}{*}{0.028} & \multirow{3}{*}{0.660} & \multirow{3}{*}{0.042} & 0.411 \\
\hline & II & $1 / 2$ & 1 & 1 & & & & & 0.261 \\
\hline & III & 1 & 1 & 1 & & & & & 0.328 \\
\hline \multirow{3}{*}{$\begin{array}{c}\text { Penalties } \\
\text { under } \\
\text { a contract }\end{array}$} & I & 1 & $1 / 2$ & 1 & \multirow{3}{*}{3.022} & \multirow{3}{*}{0.011} & \multirow{3}{*}{0.660} & \multirow{3}{*}{0.017} & 0.241 \\
\hline & II & 2 & 1 & 3 & & & & & 0.548 \\
\hline & III & 1 & $1 / 3$ & 1 & & & & & 0.211 \\
\hline
\end{tabular}

At the same time, Supplier I has a greater risk not to observe the schedule time of goods delivery as it does not have contracts with transport companies engaged in multimodal transportation and is able to go beyond the budget of a contract due to bad coordination between the business units and a lack of qualified personnel that increases the probability of failures and associated penalties. The analysis of global priorities of alternatives for the hierarchy of the criteria of the adverse event probability enables us to present a final evaluation of the study in Table 10. According to the Table 10 data we can make the following conclusion: the cumulative probability of adverse events is maximal for Supplier I, that can characterize it as the least reliable, and is minimal for Supplier III, that indicates its reliability under the considered conditions.

Table 10

The comparison of the alternatives considering the global priorities of the criteria

\begin{tabular}{|c|c|c|c|c|c|c|}
\hline $\begin{array}{c}\text { Criterion } \\
\text { Alterna- } \\
\text { tive }\end{array}$ & OP.1.2.1 & OP.1.2.2 & SP.1 & ST.1.2.1 & ST.1.2.2 & \multirow{2}{*}{$\begin{array}{c}\text { Global priority } \\
\text { of alternative }\end{array}$} \\
\hline I & 0.333 & 0.250 & 0.544 & 0.667 & 0.333 & 0.968 \\
\hline II & 0.333 & 0.077 & 0.633 & 0.411 & 0.241 & 0.900 \\
\hline III & 0.333 & 0.133 & 0.175 & 0.261 & 0.548 & 0.677 \\
\hline
\end{tabular}


To estimate losses the study included a pairwise comparison of the firstorder criteria and assessed priorities of the alternatives of the criteria chosen by a business entity, in this connection, the corresponding matrices are formed and presented in Tables 11 and 12.

Table 11

The matrix of pairwise comparisons of the first order criteria

\begin{tabular}{|c|c|c|c|c|c|c|c|c|c|}
\hline $\begin{array}{c}\text { Crite- } \\
\text { rion }\end{array}$ & PM1 & PF.1 & PI1 & PS1 & $n_{\max }$ & $C I$ & $R I$ & $C R$ & $\begin{array}{c}\text { Global } \\
\text { priority }\end{array}$ \\
\hline PM1 & 1 & 3 & 7 & 9 & & & & & 0.625 \\
\hline PF.1 & $1 / 3$ & 1 & 1 & 4 & 4.183 & 0.061 & 0.990 & 0.062 & 0.192 \\
\hline PI1 & $1 / 7$ & 1 & 1 & 1 & & & & & 0.112 \\
\hline PS1 & $1 / 9$ & $1 / 4$ & 1 & 1 & & & & & 0.071 \\
\hline
\end{tabular}

Table 12

The evaluation of the second order alternatives

by the Financial Losses criterion

\begin{tabular}{|c|c|c|c|c|c|c|}
\hline Criterion & PF.1.2.1 & PF.1.2.2 & $n_{\max }$ & $C I$ & $R I$ & Global priority \\
\hline PF.1.2.1 & 1 & $1 / 5$ & & & & 0.167 \\
\hline PF.1.2.2 & 5 & 1 & 2.000 & 0.000 & 0.000 & 0.833 \\
\hline
\end{tabular}

The results of the pairwise comparison of the first order criteria show that losses caused by breach of an international trade contract in terms of volumes and terms of goods delivery (PM1) are very significant; then, according to the importance level there are financial losses related to the increase of a contract budget (PF.1). According to Table 12, additional costs of performance of an international trade contract have the priority among the alternatives of the Financial Losses criterion (PF.1.2.2).

The pairwise comparison of the alternatives is conducted for each of the five criteria for estimating the probability of losses in performance of an international trade contract by a foreign supplier; the results of this analysis are presented in Table 13. The data showed in the table enable us to state that losses caused by breach of an international trade contract in terms of volumes and terms of goods delivery are very significant; then, according to the importance level there are financial losses related to the increase of the budget of that contract.

The analysis of the results of the pairwise comparison of the alternatives carried out in the study for each of the criteria of the hierarchy of loss assessment in performance of an international trade contract by a foreign supplier states that according to the criterion of the losses caused by breach of an international trade contract in terms of volumes and terms of goods delivery (PM1), the degree of feasibility of cooperation with each of foreign counterparties is the same. The comparison of the alternatives by the Penalties criterion (PF.1.2.1) defines Supplier I as the leader as among other business entities it is able to intensively produce various fines, and cooperation with Supplier II leads to contract appreciation during its performance, it is indicated by the comparison of the alternatives in Table 13. The disadvantages of Supplier II include his inability to work with 
buyers, a bad personnel policy, that may lead to best employees' leaving a company. The comparison of the alternatives by the criterion "Loss of competitiveness by a company" (PI1) indicates that Supplier I is not able to keep confidential and commercial information, that could damage a buyer's image. The analysis of the global priorities of alternatives based on the criteria for estimating losses in performance of an international trade contract makes it possible to calculate the resulting estimate for each alternative and present the results of calculations in Table 14.

Table 13

The analysis of the alternatives based on the criteria for assessing losses in performance of an international trade contract

\begin{tabular}{|c|c|c|c|c|c|c|c|c|c|}
\hline Criterion & $\begin{array}{c}\text { Alter- } \\
\text { na- } \\
\text { tive }\end{array}$ & I & II & III & $n_{\max }$ & $C I$ & $R I$ & $C R$ & $\begin{array}{c}\text { Global } \\
\text { priority }\end{array}$ \\
\hline \multirow{3}{*}{$\begin{array}{c}\text { Losses associated } \\
\text { with } \\
\text { breaching goods } \\
\text { volumes } \\
\text { and delivery terms }\end{array}$} & I & 1 & 1 & 1 & \multirow{3}{*}{3.000} & \multirow{3}{*}{0.000} & \multirow{3}{*}{0.660} & \multirow{3}{*}{0.000} & 0.333 \\
\hline & II & 1 & 1 & 1 & & & & & 0.333 \\
\hline & III & 1 & 1 & 1 & & & & & 0.333 \\
\hline \multirow{3}{*}{ Penalties } & I & 1 & 4 & 4 & \multirow{3}{*}{3.000} & \multirow{3}{*}{0.000} & \multirow{3}{*}{0.660} & \multirow{3}{*}{0.000} & 0.667 \\
\hline & II & $1 / 4$ & 1 & 1 & & & & & 0.167 \\
\hline & III & $1 / 4$ & 1 & 1 & & & & & 0.167 \\
\hline \multirow{3}{*}{$\begin{array}{l}\text { Additional } \\
\text { costs }\end{array}$} & $I$ & 1 & 1 & 3 & \multirow{3}{*}{3.011} & \multirow{3}{*}{0.006} & \multirow{3}{*}{0.660} & \multirow{3}{*}{0.008} & 0.416 \\
\hline & II & 1 & 1 & 4 & & & & & 0.458 \\
\hline & III & $1 / 3$ & $1 / 4$ & 1 & & & & & 0.126 \\
\hline \multirow{3}{*}{$\begin{array}{c}\text { Dismissal of } \\
\text { personnel engaged } \\
\text { in } \\
\text { contract perfor- } \\
\text { mance }\end{array}$} & I & 1 & $1 / 3$ & 4 & \multirow{3}{*}{3.015} & \multirow{3}{*}{0.007} & \multirow{3}{*}{0.660} & \multirow{3}{*}{0.011} & 0.251 \\
\hline & II & 3 & 1 & 9 & & & & & 0.680 \\
\hline & III & $1 / 4$ & $1 / 9$ & 1 & & & & & 0.069 \\
\hline \multirow{3}{*}{$\begin{array}{c}\text { Loss } \\
\text { of competitiveness }\end{array}$} & I & 1 & 6 & 8 & \multirow{3}{*}{3.034} & \multirow{3}{*}{0.017} & \multirow{3}{*}{0.660} & \multirow{3}{*}{0.026} & 0.767 \\
\hline & II & $1 / 6$ & 1 & 2 & & & & & 0.148 \\
\hline & III & $1 / 8$ & $1 / 2$ & 1 & & & & & 0.085 \\
\hline
\end{tabular}

Table 14

The comparison of the alternatives according to global priorities of assessing losses in performance of an international trade contract

\begin{tabular}{|c|c|c|c|c|c|c|}
\hline Criterion & PM1 & PF.1.2.1 & PF.1.2.2 & PI1 & PS1 & Global priority \\
\cline { 2 - 6 } Alternative & 0.625 & 0.167 & 0.833 & 0.112 & 0.071 & of alternative \\
\hline I & 0.333 & 0.667 & 0.416 & 0.767 & 0.251 & 0.770 \\
\hline II & 0.333 & 0.167 & 0.458 & 0.148 & 0.680 & 0.683 \\
\hline III & 0.333 & 0.167 & 0.126 & 0.085 & 0.069 & 0.356 \\
\hline
\end{tabular}

The Table 14 data suggest the conclusion that according to the level of possible losses in performance of an international trade contract Supplier I has the top position.

The final stage in assessment of potential suppliers by the criterion of the minimal risk of performance of an international trade contract is the combina- 
tion of the values of global priorities of the alternatives for different criteria hierarchies; the obtained results are presented in Table 15. We believe, this approach is justified as the best alternative has to the lowest value of the resulting risk estimate, which is the product of loss priorities values and the probability of adverse events.

Table 15

The risk analysis of performance of an international trade contract by an alternative supplier

\begin{tabular}{|c|c|c|c|c|}
\hline Alternative & $\begin{array}{c}\text { Probability of adverse } \\
\text { events }\end{array}$ & $\begin{array}{c}\text { Loss } \\
\text { amount }\end{array}$ & $\begin{array}{c}\text { Risk } \\
\text { value }\end{array}$ & $\begin{array}{c}\text { Risk value } \\
\text { (standardized) }\end{array}$ \\
\hline I & 0.968 & 0.770 & 0.745 & 0.466 \\
\hline II & 0.900 & 0.683 & 0.614 & 0.384 \\
\hline III & 0.677 & 0.356 & 0.241 & 0.151 \\
\hline
\end{tabular}

According to Table 15 we can conclude that the maximal risk is associated with Supplier I and the minimal one with Supplier III. Therefore, it is desirable for a company to conclude an international trade contract with Supplier III as this supplier is able to ensure the minimal risk of contract performance.

The following conclusions can be drawn from the compilation of the results of the analysis.

Disclosing methodical approaches to assessment of risks in selecting a foreign supplier the paper argues the viewpoint on the importance of evaluation of potential suppliers in revealing of infringements within performance of an international trade contract. It is substantiated that assessment of a foreign supplier is a mandatory component of the system of a company's international trade efficiency analysis. As the legislation does not specify the supplier choice for performance of an international trade contract, such assessment ensures reliability, accuracy and completeness of international trade counterparty information as well as the preliminary, current and desirably following control over the supplier's business operations. The results obtained in the study show that multicriteriality of the foreign supplier analysis is a specific feature of the activity carried out by a business entity in the field of the international trade. This means that a foreign supplier is evaluated not according to a single criterion, but a set of criteria. This approach is justified as it allows a company to show due diligence in choosing a foreign counterparty. The method of confirming reliability of potential counterparty information shapes the requirements to such study and contents of an information base.

The study proves that it is appropriate to choose a foreign supplier by the criterion of the minimal risk of an international trade contract performance. Since the risk is the product of the adverse event probability and the amount of losses associated with this event, the analysis of potential partners should take into account the criteria for assessing the adverse events probability in performance an international trade contract by foreign suppliers and the criteria for estimating losses. The neglect of such criteria reduces efficiency of a company's international trade. 
The study proposes the model for assessing the impact of uncertainties in selecting of a foreign supplier in combination with quantitative risk assessment based on the analysis of hierarchies. Such assessment provides a company with the toolware enabling it to evaluate all the components influencing performance of an international trade contract. The advantage of the proposed method is its universality as the degree of detailing of analysis control points is not limited. Therefore, we believe that the developed method can be a part of the internal control system of a business entity in assessing efficiency of its international trade.

\section{References}

[1] About assessment by arbitration courts of validity of obtaining tax benefit by the taxpayer [Electronic resource]: Resolution of the Plenum of the Supreme Court of Arbitration of the Russian Federation from 10/12/2006 № 53. Access from the legal-reference ConsultantPlus system.

[2] Martyanova O.V. A method of optimum distribution of resources at management of the foreign trade project [Text] / O.V. Martyanova //Economy and management: current problems of reforming: materials of the international scientific and practical conference. Volgograd: Volgograd scientific publishing house, 2012. Page 117-123.

[3] Martyanova O.V. Assessment of influence of the foreign trade operations on stability of the organization [Text] / O.V. Martyanova //Questions of economy and management in modern society: materials of the international scientific and practical conference. - Volgograd: Volgograd scientific publishing house, 2011. Page 164-167.

[4] Martyanova O.V. Assessment of risks in the analysis of the foreign trade contracts / O.V. Martyanova //Audit and financial analysis. 2012. № 4. Page 137-148.

[5] Martyanova 0.V. Method of assessment of standard cost characteristics of performance of the foreign trade contract [Text] / O.V. Martyanova //Economic sciences: materials $\mathrm{X}$ of the international scientific and practical conference "Modern Problems of Humanitarian and Natural Sciences". M.: Spetskniga publishing house, 2012. Page 173-178.

[6] Martyanova O.V. Model of assessment of capacity of the import organization in the conditions of unstable financing [Text] / O.V. Martyanova // Topical issues of development of social sciences: economy, right, pedagogics, sociology: materials of the international conference. Volgograd: Volgograd scientific publishing house, 2012. Page 109-117.

[7] Martyanova O.V. The reporting of the participating organization of the foreign economic activity created according to International Financial Reporting Standards: problems of the analysis [Text] / O.V. Martyanova // Audit and financial analysis. 2012. № 2. Page 52-58.

[8] Perminov A.A. Quantitative assessment of risk by means of a method of the analysis of hierarchies [Text] / A.A. Perminov // Management accounting and finance. 2011. № 3. Page 212-229.

[9] Saati T. Decision-making. Method of the analysis of hierarchies [Text] / T. Saati; translation from english. M.: Radio and communication, 1993. 316 pages.

[10] Shraybfeder J. Effective management of stocks [Text] / J. Shraybfeder; translation from English. The second edition. M.: Alpina Business of Axle boxes, 2006. 304 pages. 